\title{
The Millennium Development Goals and Rail Transport Development in Nigeria: A Critical Review
}

\author{
Akwara, Azalahu Francis \\ Department of Political Science, Federal University Wukari,Taraba State, Nigeria \\ aakwara@yahoo.com; aquara23@nokiamali.com \\ Udaw, Joseph Effiong \\ Department of Political Science, Federal University Wukari,Taraba State, Nigeria \\ ettete2001@yahoo.com \\ Ezirim Gerald E. \\ Department of Political Science, University of Nigeria Nssuka. Enugu State, Nigeria \\ ekenezirim@yahoo.com
}

\author{
Doi:10.5901/mjss.2014.v5n6p433
}

\begin{abstract}
The Millennium Development Goal (MDG) is an embodiment of development issues adopted by member nations of the United Nations Organization to accelerate the rate of development in their countries. As adopted in Nigeria, it aims at the eradication of extreme poverty and hunger; achievement of universal primary education or eradication of illiteracy; promotion of gender equality and empower women; reduction of child mortality; maternal health improvement; combating of HIVIAIDS, malaria and other diseases; ensuring environmental sustainability; and the development of global partnership for development. These objectives are incorporated into the development agenda of the various member states. The achievement of these goals will among other things depend on the availability of necessary and sufficient infrastructural development in the countries, especially a developed transport system. This study examines the role transportation would play towards the realization of these MDGs in Nigeria. And each of these goals are examined in connection with their transportation factor requirements; and the consequences the lack (or inadequacy) of this factor can bear on fulfilling the Goals. The paper finds that the transport requirements for the achievement of these goals in Nigeria are lacking, especially in the rail transport sector. While appreciable progress is being made to develop the other transport sectors viz: air, road and water transport, the rail transport sector suffers neglect. The paper finds that the law establishing the railway makes the rail system an exclusive reserve of the Federal Government in Nigeria, and that this has prevented private participation in the sector and has led to the underdeveloped nature of rail transport system in the country and this inhibits the achievement of the millennium development goals in the country. The paper recommends the review of the act to allow for private participation in the sector to reposition the sector to provide the necessary transport services necessary for the realization of the millennium development goals in Nigeria.
\end{abstract}

Keywords: development; transportation; gender-equality; empowerment; poverty eradication.

\section{Introduction}

The Millennium Development Goal (MDG) is an embodiment of development issues adopted by member nations of the United Nations Organization to accelerate the rate of development in their countries. As adopted in Nigeria, it aims at the eradication of extreme poverty and hunger; achievement of universal primary education or eradication of illiteracy; promotion of gender equality and empower women; reduction of child mortality; maternal health improvement; combating of HIVIAIDS, malaria and other diseases; ensuring environmental sustainability; and the development of global partnership for development. These objectives are incorporated into the development agenda of the various member states and are facilitated through human interaction, availability of appropriate infrastructural facilities and good governance.

In every human society, interaction is unavoidable. This is more so when a defined geographical space (such as Nigeria) is variedly endowed with human and material resources in significant quantities. Such condition necessitates exchange among individual and group components of the society, thus implying transport-demand. Munby (1968) attests 
that transportation is an indispensable need of every human society no matter its mode of operation.

It, therefore, becomes imperative that state planners and policy-makers must lend ample consideration to the means and modes of both human and material mobility. Transportation is not sought after for the purpose of mere movement. Relocation of materials and labour impact on economic values of items are also involved. This fact is underscored by Adefolalu (1977), who identified transportation as a phase in the production process. In his view, production process is complete only when the goods produced get to the final consumer. Odugbemi and Ajiboye (1998) recognized the vital role transportation plays in achieving effective distribution or logistic chain. In this connection, commerce and other economic activities often largely account for transport-demand. By extension, it can be established that the quantum of economic activities in a society significantly impacts on the general well-being of its members.

In specific terms, a country such as Nigeria can be said to aggregately experience development only when there is improvement in both individual and collective well-being of her populace. In this trajectory, we realize that transportation is pivot to human activities and wealth creation.

Based on the foregoing, this discourse dwells on the Millennium Development Goals (MDGs), as a global blueprint for improving the lot of mankind. It is the extent to which this blueprint addresses transportation and transport development that this paper seeks to inquire. Specific focus is on Nigeria. The MDG document is appraised in the light of deliberate and specific statements that target transport infrastructural development.

\section{Statement of Problem}

The Nigerian railway system has been in existence since 1898 and its existence was given a legal backing through an Act establishing the Nigerian Railway Corporation (NRC) in 1955. The 1955 Act forbids any organization, individual or group to carry out any railway activity. In other words, railway operation in Nigeria is an exclusive prerogative of the federal government. This legislation, sadly, accounts for the near-moribund state the NRC finds itself today. While the road and air mode sectors were developed in the post-civil war infrastructural development agenda, the rail sector development was neglected. The result of this trend is the near-comatose state the rail system finds itself in Nigeria. Considering the importance of transportation in the socio-economic development processes of a country as Nigeria, it becomes imperative to investigate what are Nigeria's millennium development goals in the transport sector and how have the goals addressed the problems in the railway transport system in the country. What are the challenges ahead and what are the solutions.

\section{Theoretical Orientations and Development Models in Public Policy Planning and Administration}

The term, 'development', is relative when viewed in the context of public administration. In the view of Ali (2011), what defines development in third world countries largely lies in the avoidance of social unrest and the maintenance of power. When viewed against Rostow's (1960) identified stages of economic growth model, it means that third world countries are at the stage of pre-condition for take-off into self-sustaining growth. It is in the atmosphere of tranquility that other developmental and indeed, advance stages of growth can be attained. Whereby a society is still grappling with sustenance of social stability, further development and growth activities are stalled. According to Rostow's model, the required mix of savings and investment through national planning and capital investment forms the basis for achieving developmental growth.

Another model of development is premised on false paradigm-theory. According to this school of thought, underdevelopment is caused by faulty and inappropriate advice from international 'experts'. In this connection, lapses in international organization recommended policies can be suspect when they do not address the specific and obvious needs of some of its beneficiaries or members.

Rodney's (1972) concept of development is specifically in the African perspective. Issues such as illiteracy, hunger and poverty were identified by Rodney as primary debilitating factors of development in Africa. According to him, development begins when the rhetoric questions that address illiteracy, hunger and poverty are answered. It should be noted that just addressing these development foundational issues only brings a society to a pre-condition for contemporary development. It is the substantial aggregate improvement in the well-being of members of a society that defines development. Sustainable methods of exploiting nature are, therefore, emphasized as a vital feature of development in the real sense. Other models of development in public administration are built around institutional, incremental and comprehensive changes. These are all issues that are more appreciated in terms of their sustainability value. These are the issues to be addressed by the millennium development goals in various nations of the world. 


\section{Transport-Need and Transport Development in $21^{\text {st }}$ Century Nigeria}

With a landmass of over 900,000 square kilometers, Nigeria's topography is suitable for all modes of transport. Water, rail, road, air and pipeline modes that dot parts of the country are, majorly, legacies that represent neo-colonial exploitation. Ports were developed to serve as western and eastern inroads/gateways for agro-based raw materials in and out of Nigeria to Europe, especially. Rail network was designed to complement colonial transport plan of linking the hinterland of the northern parts with the coasts of Lagos and Port-Harcourt.

Fifty-two years after independence, these transport infrastructures still remain primary in Nigeria's transport system. While the maritime sector has been developed in terms of capacity and fair country-wide spread, the rail sector continues to be bogged by systemic neglect. It is to this rail transport sector that discourse now turns.

Although the Nigerian railway system has been in existence since 1898, the Act establishing the Nigerian Railway Corporation (NRC) was instituted in 1955. The 1955 Act forbids any organization, individual or group to carry out any railway activity. In other words, railway operation in Nigeria is an exclusive prerogative of the federal government. This legislation, sadly, accounts for the near-moribund state the NRC finds itself today. While the road and air modes sectors were developed in the post-civil war infrastructural development agenda, the rail sector development was neglected. The result of this trend is the near-comatose state the rail system finds itself in Nigeria. However, there are committed moves made by the current government of President Goodluck Jonathan to review the Act. Presently, the bill in that respect has received a second reading in the national assembly (Nigerian Pilot, 2012). As a proactive measure, the federal government has embarked on a 25-year strategic vision of repositioning and modernizing the existing rail system.

Considering the Millennium Development Goals (MDGs) as a long-term developmental agenda, transportation is crucial to almost every sector this agenda seeks to address. Again, the sustainability objective which the MDGs roadmap holds can be largely achieved through effective and efficient transport provision.

\section{MDGS and Nigeria's Transport Development Plan}

At this juncture, it is appropriate to appreciate the MDGs in the light of transport relevance. Each of the broad-based eight Goals is considered vis-à-vis transport relevance in achieving specific targets of the goals. Due to volume constraint, we refrain from elaborate listing of goals' targets. Rather, goals and their relevant targets are mentioned only for the purpose of enunciation.

The broad-based Goals of the MDG roadmap are as follow:

Goal 1: Eradication of extreme poverty and hunger;

Goal 2: $\quad$ Achievement of universal primary education;

Goal 3: $\quad$ Promotion of gender equality and empower women;

Goal 4: $\quad$ Reduction of child mortality;

Goal 5: $\quad$ Maternal health improvement;

Goal 6: $\quad$ Combating of HIVIAIDS, malaria and other diseases;

Goal 7: $\quad$ Ensuring environmental sustainability; and

Goal 8: Development of global partnership for development.

Source: www.un.org/documents/ga/res/55/a55r002.pdf - A/RES/55/2 (2000)

Each of these goals are examined in connection with their transportation factor requirements; and the consequences the lack (or inadequacy) of this factor can bear on fulfilling the Goals.

\subsection{MDG goal 1: Eradication of extreme poverty and hunger:}

The eradication of extreme poverty and hunger is a two-pronged initiative. Hunger and poverty are mutually inclusive socio-economic phenomena. From a holistic perspective, Goal 1 is directed at food security. By inference, agro-based and agro-allied activities and production are involved. The importance of transportation in agricultural production is expressed by Ajiboye (2011). Transport efficiency and effectiveness affect the basic functions of production, distribution, marketing and consumption. From the foregoing, it is clear that both hunger and poverty alleviation (and possibly, eradication) can be achieved when efficient transportation infrastructure are provided and made accessible. It must be stated here that agricultural transport-needs vary widely because of seasonality and the nature of products. Abumere and 
Oluwasola (2001) are of the opinion that losses that could arise from lack of appropriate transport facility; and product spoilage can be curtailed once transportation inadequacies are addressed.

\subsection{Goal 2: Achievement of universal primary education;}

Goal 2 is focused on education. More so, children form the nucleus of targeted beneficiaries. And, as a persuasive public policy, incentives for acceptance and compliance are imperative. Various government gestures such as: free school feeding, stipends, free textbooks and uniforms (among others) aimed at encouraging primary school enrolment and attendance can only be complemented by transport provision. In Nigeria, the Enugu State Government has a free-ride-toschool (and return) scheme for primary and secondary school students, within the 'Coal City'. Access to primary school facilities, especially in rural communities, is marked by long distances to some homesteads. The lack (or inadequacy) of appropriate transport means for the rural school children, who are part of the over seventy percent of the 140 million citizens can be a great impediment to achieving the target of ensuring that children (everywhere) will be able to complete a full course of primary school.

Provision of adequate means of transportation serves as ample motivation to students, teachers and other school staff. Besides, it provides the relaxed platform learners and teachers require for pre-classroom and post-classroom engagements. It is in this enabling teaching and learning conditions that the benefits of education can be maximally attained for development.

\subsection{Goal 3: Promotion of gender equality and empower women;}

Goal 3 is closely related to Goal 2. The marked differences lie in gender emphasis. For the purpose of elucidation, it is pertinent to enumerate some of the progress-monitoring indicators of this Goal at this point. These indicators are as follows:

- Ratios of girls to boys in primary, secondary and tertiary education

- Ratio of literate females to males of 15-24 year-olds

- Share of women in wage employment in the non-agricultural sector

- Proportion of seats held by women in national parliament

It is expected that the measurable parameters of these indicators rise in favour of female. Yet, the fact still remains that education is key to achieving them. In the same vein as Goal 2, the transportation factor is substantially relevant to attaining the first two indicators. Other indicators are offshoots of the first two. The argument can therefore be rested on the premise that transportation is vital to the foundation for women empowerment.

5.4 Goals 4, 5, and 6: Reduction of child mortality; maternal health improvement; and combating of hiv/aids, malaria and other diseases;

Goals 4, 5 and 6 share a common sectoral base. The focus of these three goals strongly relate to health. But we must not lose trend of this discourse which is the relevance of transportation in the fulfillment of the MDGs, especially these three under consideration. Issues of child mortality, maternal health, and disease prevention require institutional infrastructural facilities. These facilities are at locations. Therefore, public transport means (vehicles) and infrastructure (roads) for accessing such places are equally as important as the facilities themselves. Yet, transportation implications of these lifesaving cum life-improving initiatives are given less consideration. It must be stated, here, that no matter how wellintended a public policy or project might be, accessibility of such project to targeted individuals is paramount. In many ways, transportation and health correlate paradoxically either in terms of ease of access to facility (especially in emergency cases), or accident causality. For instance, Obi and Odumosu (2011) observed that although HIVIAIDS has a far-reaching impact on all sectors of the Nigerian economy, the transport sector employees were identified as being particularly vulnerable. It was further recognized that Long-Distance Drivers (LDDs) play a central role in promoting the spread of HIVIAIDS in Nigeria. In a related effort, Morenikeji and Adegoke (2004) resorted to the training of peer educators, among transport workers. The objective of using peer educators is to achieve a multiplier effect of awareness within the transport sector.

Goal 7, perhaps, bears the most contemporary transportation-related focus. Environmental sustainability subsumes issues such as gaseous emissions and ozone depletion, energy-use, maintenance of biological diversity 
among others. Development is said to be sustainable only if consuming activities of the present has minimal negative impact on the future. Increasing household vehicle ownership in Nigeria poses serious environmental challenge. As Walsh (2003) observed, a common source of environmental pollution is vehicular emission. They are major sources of volatile organic compounds (VOCs) and nitrogen oxides, the precursors to both tropospheric ozone and acid rain; carbon monoxide (CO); toxic air pollutants such as diesel particulate; and chlorofluorocarbons (CFCs). Yet, not even the Goal 7 target is definite on substantial transportation regulation to mitigate the sector's contribution to pollution. Rather, the MDG document generically admonishes countries to integrate the principle of sustainable development in their policies and programmes; and reverse the loss of environmental resources.

\subsection{Goal 8: Development of global partnership for development}

Lastly, Goal 8 which focuses on global partnership for development has numerous targets. But the point still remains that whether in bi-lateral or multi-lateral relationship among nations, trade is often implied. Although such trades usually involve exchange of goods and services, physical products (in the forms of raw materials and finished items) dominate the transactions. Here, again, the massive deployment of vehicles for transportation is almost inevitable. Yet, none of this Goal targets denotes deliberate policy or action in respect of transportation. Rather, the document is concerned with fiscal issues such as Official Development Assistance (ODA), tariffs, debt management, GDP among others. Other areas of physical concerns include essential drug availability, youth job-creation, Information and Communication Technology (ICT) and the special needs of landlocked countries and Small Island Developing States (SIDS).

\section{The Importance of Transportation in the Achievement of the MDGs}

Transportation, no doubt, is a vital factor for human interaction and communication. A country such as Nigeria, which is variedly endowed with resources, will naturally stimulate interaction among locations where there are surpluses and lack. The Millennium Development Goals (MDGs) Declaration was signed by 189 countries, including 147 Heads of State, in September 2000 as a global policy agenda, targeted toward ensuring an overall objective of sustainable mankind development. The MDGs have targets that are inter-related. These Goals and targets represent partnership between developed countries and developing countries. According to the Declaration, such partnership is determined toward creating an environment - at national and global levels - conducive to development; and elimination of poverty. Partnership objective of this magnitude inevitably involves trade and commerce. Thus, transportation becomes crucial. It is in the light of transportation factor that this paper examined the Goals of the Declaration to determine the level of consideration given to it.

While appraising the MDGs and their relevant targets, it is observed that the document has selected sectoral focus in agriculture, education, social justice, health, environment and international relations. Health is given a generous focus due to the fact that true well-being lies in good state of health - credence to the cliché: "Health is wealth". In all of what the MDGs seek to address, we observed that transportation is pivotal to their realization. It is so much so that the nonrecognition and non-inclusion of transportation infrastructure development in the Declaration is identified, by this paper, as a flaw in the document.

Relevant Goal targets and indicators for monitoring their progress imply transportation infrastructure requirements in order to achieve and assess them. Yet, no deliberate pronouncement of transportation development is in the agenda. Such acts of omission, in Killik's (1983) view, form the sources of weaknesses in plan implementation. Other sources Killik identified include deficiencies in plan documents; institutional and bureaucratic weaknesses (including inadequate planning resources); exogenous shocks; and political factors. No doubt, the lack of emphasis on transport infrastructure and service development in the Declaration is a deficiency in the plan document of MDGs.

\section{Conclusion}

With almost three years to the MDGs' fulfillment target time (2015), some indicators for monitoring the Goals' progress continue to largely depend on transportation elements. For instance, the proportion of population living below $\$ 1$ per day can be reduced if adequate rural road infrastructure is available for agro-product evacuation since about $70 \%$ of the Nigerian population is agrarian. In the same vein, scholars such as Egbuna (2001) as well as Ajiboye and Afolayan (2009) identified dearth of transport infrastructure and services as major factors militating against food production and circulation in developing world.

Access to healthcare facilities in order to reduce infant and maternal mortality rates, as well as accessing skilled 
health personnel, promptly depends on effective and efficient transportation provision. The same ease of access is also required for educational facilities. Perhaps, the most prominently transportation-related Goal is that of environmental sustainability. Reduction in ozone-depleting emissions substantially requires addressing regulations in respect of vehicle emissions. Such regulations are imperative in view of the transportation effects the global partnership Goal can spin-off. The secondary position which the MDG document accords transportation is, indeed, a major flaw in the global effort at facilitating human development.

\section{Recommendations}

In view of the foregoing discourse, and the ensuing observations, the following recommendations are hereby put forward:

1. The MDG targets must emphasize adequate transport provision in order to reinforce their realization.

2. The Nigerian railway system must be developed, as relative bulk carrier, in order to garner the benefits of carbon footprint reduction and fuel efficiency.

3. There is urgent need to review the 1955 Railway Act in order to encourage private participation.

4. Appropriate transport infrastructure such as roads and vehicles should be provided in all modes to facilitate access.

5. Effective legislation aimed at regulating toxic automotive emission must be put in place.

6. There is need for dedicated and integrated intermodal transport system to accentuate MDG efforts of the Nigerian government to fulfillment.

These recommendations serve as policy remediation, or addendum, aimed at addressing the MDG agenda flaw of relegating transportation imperativeness. As aptly recommended by Huzzayyin (2005), sustainable transport development within the context of developing countries must meet the requirements of inexpensiveness, simplicity, durability, self-support, accessibility, cleanness and social acceptability. In the light of these requirements, Odeleye (2011) highlighted the need for Nigeria to join the league of other developing countries such as Egypt and Mexico in the utilization of Compressed Natural Gas (CNG) in public transportation.

The MDG platform provides a launch-pad for attaining the continental goal of New Partnership for Africa's Development (NEPAD). At the level of the Nigerian statehood, the National Economic Empowerment and Development Strategy (NEEDS) can be factored to deal with the observed lapses of the MDG Declaration. After all, the MDG programme is a blueprint that accommodates initiatives which will ultimately lead to the set objective of development and poverty reduction.

\section{References}

Abumere, S.T. and Oluwasola O. (2001). "Food Supply to Ibadan: A Study of Rural-Urban Linkage". Research Report No. 29, Development Policy Centre, Ibadan.

Adefolalu, A.A. (1977). "Significance of Transportation" in, Rural Development in Environmental and Spatial Factors. Proceedings of 20th Annual Conference of Geographical Association of University of Ife, lle-Ife.

Ajiboye, A.O. (2011). "The Effects of Transportation System on Food Marketing and Security in Nigeria" Journal of Logistics and Transport, vol. 4 (1), pp. 53-68.

Ajiboye, A.O. and Afolayan, O. (2009). "The Impact of Transportation to Agricultural Production in a Developing Country: The Case of Kolanut Production in Nigeria" International Journal of Agricultural Economic and Rural Development, vol. 2(2), pp. 49-57.

Ali, A.A.G. (2011). "Development Planning in Africa: Key Issues, Challenges and Prospects". A Background Paper commissioned by the United Nations Economic and the Social Council, Economic Commission For Africa (UNECA) at the Meeting of the Committee of Experts of the 4th Joint Annual Meetings of the AU Conference of Ministers of Economy and Finance and ECA Conference of African Ministers of Finance, Planning and Economic Development. Addis Ababa, Ethiopia.

Egbuna, E.N. (2001). "Food Security in Nigeria: the Challenges and Way Forward" a Selected papers presented at the 2001 Annual Conference on Natural Resource-Use, the Environment and Sustainable Development. The Nigerian Economic Society, pp.307326.

Huzzayyin, A.S. (2005). "Impeding the Promotion of Sustainable Transport in Developing Countries: Views on the Constraints". In International Conference on Sustainable Transportation in Developing Countries proceedings, Abu-Dhabi, United Arab Emirate.

Killick, T. (1983). "Development Planning in Africa: Experiences, Weaknesses and Prescriptions"; Development Policy Review, vol. 1, pp. $47-76$.

Morenikeji, A.M. and Adegoke, D. (2004). "HIV Infection Prevention among Road Transport Workers in Ojo LGA of Lagos State" in, International Conference on AIDS, abstract no. TuPeE 5384

Munby, D.I. (1968)(ed.) Transport: Selected Readings. Harmondsworth Pengun. Washington D.C. 
Nigerian Pilot Newspaper (2012). http://nigerianpilot.com/index.php/business/4856-fg-nass-agree-to-amend-nrc-act-1955. Electronically retrieved on November 17, 2012.

Obi, P. and Odumosu, A. O (2011). "Erudification and Edification of Inter-State Heavy Goods Vehicles (HGVs) Drivers on HIVIAIDS Spread" Journal of Logistics and Transport, vol. 4(1), 1-12.

Odeleye, J. (2011). "Natural Gas as Alternative Source of Energy for Sustainable Public Transportation in Nigeria" Journal for Logistics and Transport, vol. 3 (1), pp. 11-21.

Odugbemi, O.O. and Ajiboye, A.O. (1998). "Transport Factor in Cash Crop Production and Distribution: The Kolanut Example" Journal of Transport Studies, 2(1) pp. 89-106.

Rodney, W. (1972). How Europe Underdeveloped Africa. Bogle-L'ouverture Publications, London.

Rostow, W. W. (1960). The Stages of Economic Growth: A Non-Communist Manifesto, Cambridge: Cambridge University Press.

Walsh, M.P. (2003). "Vehicle Emission Trends and Forecasts: The Lessons of the Past 50 Years" in, Blue Sky in the 21st Century Conference, Seoul-Korea. 
